\title{
THE EFFECTIVENESS OF STORY COMPLETION TOWARD STUDENTS' SPEAKING ABILITY
}

\author{
Ida Yulianawati ${ }^{1}$, Sulastri ${ }^{2}$ \\ English Education Departement, Wiralodra University \\ E-mail: idayulianawati90@gmail.com ${ }^{1} \underline{\text { sulastrijunedi@gmail.com }}^{2}$
}

\begin{abstract}
Speaking is an activity used by people to communicate with others. According to Zhang (2009), speaking remains the most difficult skill to master for the majority of English learners, and they are still incompetent in communicating orally in English". Many people are difficult to speak English. This research aims to find out the effectiveness of Story Completion effective toward students' speaking skills. To solve the problem above, the writer would like to apply the story completion technique in teaching speaking from Kayi (2006). Quasi-experimental was applied as the method of the research. The research was conducted in SMA N Krangkeng with 66 participants; 34 students from X MIPA 1 as the control group and 32 students from X MIPA 2 as the experimental group. To collect the data, a speaking test was given to the participants.Based on the statistical analysis the technique of story completion was successfully improved the students' speaking ability.
\end{abstract}

Keywords: Story Completion, Speaking Ability

\begin{abstract}
Abstrak
Berbicara adalah sebuah aktifitas yang digunakan orang untuk berkomunikasi dengan yang lain. Menurut Zhang (2009), berbicara merupakan keterampilan yang paling sulit untuk dikuasai bagi para pembelajar Bahasa Inggris, dan mereka masih tidak cukup kompeten untuk berkomunikasi secara oral dengan menggunakan Bahasa Inggris. Banyak orang mendapatkan kesulitan untuk berbicara menggunakan Bahasa Inggris. Penelitian ini bertujuan untuk menguji dan mencari jawaban efektifitas dari Story Completion terhadap keterampilan berbicara peserta didik. Untuk menyelesaikan masalah ini, peneliti menggunakan teknik Story Completion dalam mengajar berbicara yang di adopsi dari Kayi (2006). Penelitian semi eksperimen digunakan sebagai metode penelitian ini. Penelitian ini dilaksanakan di SMA N Krangkeng dengan jumlah partisipan 66 peserta didik; 34 peserta didik kelas X MIPA 1 sebagai kelas control, dan 32 peserta didik kelas X MIPA 2 sebagai kelas eksperimen. Untuk mengumpulkan data, peneliti memberikan tes berbicara kepada para peserta didik. Berdasarkan pada analisis statistic, teknik Story Completion telah mampu meningkatkan keterampilan berbicara peserta didik.
\end{abstract}

Kata kunci: Story Completion, Kemampuan Berbiacara 


\section{INTRODUCTION}

English is one of a foreign language that is taught at each level of Indonesia education from elementary school until university. The students are demanded to master it, because through speaking they could deliver information well to others and of course the need for communication. Besides, speaking also can be a tool for students to express their feelings, ideas or opinions. According to Richard and Renandya, (2002: 210), Speaking is one of the central elements of communication. Speaking is seen as the central skill. The desire to communicate with others, often face to face and real-time drives us to attempt to speak fluently and correctly. In the learning process speaking is one of the skills that students have to do. Therefore communication or speaking is the goal of English language teaching is to develop student ability in using English. Communication will not be running well without speaking and it is an essential way in which the speakers can express themselves through the language. It can be monologs, speeches, telling the story, short conversation or reading aloud. A teacher should prepare themselves to make the students more active in the classroom. The teacher needs to know how to make students speak in the classroom. To reach it, the teacher needs to use one strategy or technique in the teaching process. It is correspondingly asserted by Cole (2008) that it is the teacher's role to provide effective plans/strategies in accomplishing students' educational needs, whose general purpose is to communicate using the language being learned. These imply that it is teachers' responsibility to make students speak English by employing suitable teaching strategies of speaking.

Based on the 2013 curriculum, the students in the tenth grade of Senior High School level have to be able to tell the meaning of essays in the form of narrative text, about simple narrative text in the form of legend story, according to the context of their use with pay attention to the social function, structure and correct language features based on the context, descriptive, and news item 
to the others orally in the context of daily conversation. It means that it is important for students to have a lot of speaking practices so that they can speak fluently.

Considering the problems above, the writer tried to apply the story completion technique in teaching speaking ability. According to Kayi (2006), story completion is a free-speaking activity for which students sit in a circle for this activity, a teacher starts to tell a story, but after a few sentences, he or she stops narrating. Then, each student starts to narrate from the point where the previous one stopped. Each student is supposed to add from four to ten sentences. Students can add new characters, events, description and so on. Based on the explanation above, this research leads to the investigation on how is the real ability of students' speaking skills in the classroom and whether this story completion technique is effective for senior high school students.

In line with the problems, then research was conducted to (1) to know the students speaking ability, and (2) to know the effectiveness of story completion technique toward students' speaking ability.

Some reviews of related theories are given to hand over deep understanding of the research.

\section{a. Speaking}

Speaking is one of the four language skills (reading, writing, listening and speaking). It is the means through which learners can communicate with others to achieve certain goals or to express their opinions, intentions, hopes, and viewpoints. Besides, people who know a language are referred to as 'speakers' of that language. Furthermore, in almost any setting, speaking is the most frequently used language skill. Cameron (2001:40) defines "speaking is the active use of language to express meanings so that other people can make sense of them". People can express their idea, feeling on their minds to others directly. Speaking does not only deal with correct pronunciation, the use of grammatical structure, and appropriate words, but also with the proficiency of how the way to convey meaning to make the 
listeners understand what is being talked about.

Brown (2000:271) describes six categories of speaking skill areas. Those five categories are a) Imitative the point of this category includes the ability to practice intonation and focusing on some particular elements of language form. b) Intensive the point of this type is the students' speaking performance that is practicing some phonological and grammatical aspects language. It usually places students doing the task in pairs (group work). c) Responsive is interaction and test comprehension but at a somewhat limited level very short conversation. d) Interactive is the length and complexity of the interaction which sometimes includes multiple exchanges and/or multiple participants. e) Extensive this type is the teacher gives students extended monologues in the form of oral reports, summaries, storytelling, and short speeches.

Speaking problems are some problems that make someone lacks speaking ability. According to Davies and Pearse (2000) language, problems serve as one of the important reasons behind the poor academic performance. These problems may become obstacles for students to enhance and improve their speaking ability. The reasons why the students are having problems in their speaking are they are poor in grammar, vocabulary, and pronunciation. Those problems belong to linguistics problems.

\section{b. Story Completion Technique}

Story Completion is a freespeaking activity for which students sit in a circle for this activity, a teacher starts to tell the story, but after a few sentences, he or she stops narrating. Then, each student starts to narrate from the point where the previous one stopped. Each student is supposed to add from four to ten sentences. Students can add new characters, events, description and so on. (Kayi:2006). Story completion is one of a new technique in teaching speaking of narrative text which can increase the students' speaking skills. It might be caused by the real-life situation of the class which can make the students interested in following the lesson (Kayi: 2006) who states 
that story completion is an activity which very enjoyable in the whole class. The learners will easily be plunged into the plots of the story as they had to tell the part of the story decided.

This technique helps students' speaking skills improving. In this type of teaching students' creativity also improve; in contrast to story retelling, in this technique, students must use the vocabulary of their own. This is an open task and it is students who manage the story and try to complete it.

The procedure of Story Completion technique stated by (Kayi:2006) as follows:

1. The teacher asks students to make groups consist of 6 students in each group.

2. The teacher gives the topic of a narrative text, the teacher gives them 20 minutes to discuss with their group.

3. The teacher starts to tell a story in the beginning

4. After a few sentences, he or she stops narrating
5. Then, each student starts to narrate from the point where the previous one stopped.

\section{METHOD}

In this research, the writer used a quantitative approach with the use of the experimental method. According to Nunan (1992:230), Experimental research is a procedure for testing a hypothesis by setting up a situation in which the strength of the relationship between variables can be tested. According to Creswell (2008:309), quasi-experiment is experimental situations in which the researcher assigns, but not randomly, participants to groups because the experimenter cannot artificially create groups for the experiment. Furthermore, the writer applied the Pretest and Posttest design. Creswell (2008:297) explains that a pre-test provides a measure of some attributes or characteristics that will be assessed for participants in an experiment before they receive treatment. Meanwhile, a posttest is a measure of some attributes or characteristics that will be assessed 
for participants in an experiment after a treatment. QuasiExperimental Design has many designs. Gay (2009:270) explains that the non-equivalent control group design involves random assignment of intact groups to treatments, not a random assignment of individuals. The population was students in SMA $\mathrm{N}$ Karangampel with two classes as the sample; X MIPA1 (34 students) as control class and X MIPA 2 (32 students) as an experimental class.

\section{FINDINGS AND DISCUSSION}

Based on the observation that was done by the researcher, sixty-six students practiced their speaking in a group. To support the research, the writer used quasi-experimental as a research method.In this research method, two samples have been observed, control class and experimental class. The writer gave pretest and posttest to both classes. The treatment was only given to the experimental class. In this case, the writer gave treatment to the students by implementing the story completion technique. To get the data for the initial condition of students speaking ability, the writer gave pretest the students in Experimental class and Control class. It can be seen in the following table:

Table 1. The Measurement of Pre-test In Control Class and Experiment Class

\begin{tabular}{|c|c|c|c|}
\hline \multirow{2}{*}{ Class Interval } & \multirow{2}{*}{ Category } & Control Class & Experiment Class \\
\cline { 3 - 4 } & & Pre Test & Pre Test \\
\hline $90-100$ & Excellent & 0 & 0 \\
\hline $80-89$ & Very good & 1 & 1 \\
\hline $70-79$ & Good & 7 & 6 \\
\hline $60-69$ & Enough & 14 & 9 \\
\hline $50-59$ & Poor & 5 & 10 \\
\hline $0-49$ & Very poor & 5 & 8 \\
\hline
\end{tabular}

From the result, we can see that there more than half of the total students in both classes got scores under the KKM. There were 24 in the control class and 27 in the experimental class. It can be concluded that their speaking ability needs to be improved. So the writer 
gave the story completion technique as a treatment to the students in the experimental class. The story completion technique was used by students in a free-speaking activity where they were in a group. Before starting the speaking activity, the writer gave an ice breaker, like a game about asking questions to make the students relaxed and understand whether they were focused or not. Activity before introduced and explained about story completion technique in teaching English by using a topic that has been determined. The writer reviewed the material about narrative text especially the legend story before she introduced and explained the story completion technique.

After the writer gave the treatment, the writer gave the posttest to the students. The post-test was used to know the students speaking skills, especially in story completion after applying the treatment. Both classes were given the same pre-test and post-test. The text type used in both tests was narrative text. The form of the test was oral presentation test. The writer gave a narrative text with a legend story as a topic. The writer asked the students to make some groups. Then the writer told them the title of the story and they should present it in front of the class.

Table 2. The Measurement of Post-test in Control Class and Experiment Class

\begin{tabular}{|c|c|c|c|}
\hline \multirow{2}{*}{ Class Interval } & \multirow{2}{*}{ Category } & Control Class & Experiment Class \\
\cline { 3 - 4 } & & Post Test & Post Test \\
\hline $90-100$ & Excellent & 0 & 4 \\
\hline $80-89$ & Very good & 4 & 14 \\
\hline $70-79$ & Good & 3 & 11 \\
\hline $60-69$ & Enough & 13 & 5 \\
\hline $50-59$ & Poor & 9 & 0 \\
\hline $0-49$ & Very poor & 3 & 0 \\
\hline
\end{tabular}

The minimum mastery of the first grade of senior high school is 70 , from the result we can see that 29 students got the score above the KKM and only 5 students got scores under the KKM in the experimental class. There were only 7 students who got the score above KKM and 25 students got scores under the KKM in control class. It can be 
concluded that students' speaking ability is improved after the story completion was implemented in teaching speaking.

\section{Students Speaking Ability}

To find out the ability of students in speaking, the writer gave a pre-test. The pretest was done to know the initial condition of their speaking and the posttest was given to know the condition of their speaking after treatment. Both tests were in the form of intensive speaking. According to Brown (2000:271), there were six categories of speaking skill areas. Those five categories are imitative, intensive, responsive, interactive and extensive. The test used in this study is intensive speaking. It is students' speaking performance that is practicing some phonological and grammatical aspects of language. It usually places students doing the task in pairs (group work), for example, reading aloud that includes reading a paragraph, reading the dialogue with a partner in turn, etc. To measure their speaking ability, the writer followed the criteria at speaking assessment from Brown ( 2004:172173). There were five criteria to asses students speaking skills; grammar, pronunciation, vocabulary, comprehension, and fluency. The highest score in those tests was 100 while the lowest score was 0 .

In this section also the writer explains the students' achievement of pre-test in both classes that control class and experimental class. There are 5 students with a score of $00-49$ who got a very poor category. The students with this score, they have the same problems. Their problems were very low in 5 criteria of speaking assessment, such as grammar, vocabulary, pronunciation, comprehension, and fluency. There are 5 students with a score of 50-59 who got a poor category. The problems of students in this category are pronunciation, grammar, and vocabulary. According to Spolsky \& Hult (2008), generally, linguistics comprises the detailed vocabulary, grammar, and pronunciation. Linguistics problems are those problems that make students speaking ability become poor. There are 14 students with a score of 60-69 
who got enough category. They were good in vocabulary, comprehension, and fluency but they were not good in grammar and pronunciation. According to Hornby (2008:352), pronunciation is a way in which a language or particular word or sound is spoken. Pronunciation is very important to be learned, especially in speaking skills. Pronunciation is how people make a sound of words. However, many students find pronunciation as one of the most difficult aspects of learning English especially speaking. According to Hinkel (2005:491), a second language learner needs to master the individual characteristic of the sound of a new language. There is only 1 student with a score of 80-89 who got a very good score. She was good enough in grammar, and vocabulary, fluency, comprehension, and pronunciation. There are no students who got an excellent category.

While the students' achievement of experimental class in the pre-test is lower than the control class. It can be seen that 8 students with the score 0-49 got very poor category, 10 students with the score
50-59 got poor category, 9 students with the score 60-69 got enough category, 6 students with the score 70-79 got good category, 1 student with the score 80-89 got very good score, and there are no students who got excellent category.

\section{The Effectiveness of Story Completion Technique}

As stated at the beginning of chapter 1 , the discussion is focused on the effectiveness of story completion toward students' speaking ability. So the writer would concern to discuss the story completion technique. According to Kayi (2006). Story completion is very enjoyable in a free-speaking activity where students sit in a circle. In this activity, a teacher starts to tell a story, but after a few sentences, he or she stops narrating. Then, each student starts to narrate from the point where the previous one stopped. Each student is supposed to create four to ten sentences. Students can add new characters, events, descriptions and so on. Based on the explanation of the theory there is no gap between 
the research conducted with the theory.

\section{Pre Test}

The result of the pretest led us to the conclusion that most of the students were under the Minimum Mastery Criteria. They mostly had problems in terms of grammar, vocabulary and pronunciation and comprehension. Since there were 27 students were included into very poor to enough category in experimental class thus the writer continued to give treatment to them.

\section{Treatment}

The writer only gave treatment to the students in the experimental class, it was the story completion technique.

The first step was opening; the writer entered the class, started to study and begun with a greeting and praying. After that, the writer asked some questions to the students about a narrative text.

The second step was brainstorming, the writer retells the story of Malin Kundang to the students. After a few sentences, the writer asked the students to continued the story until done. The students were very enthusiastic in a speaking activity. So the story of Malin Kundang was done comprehensively.

The third step was explaining the story completion technique. The writer began to explain about the story completion technique in speaking. Then, the writer explained the procedure of the story completion technique, in a group. The writer asked the students to make groups before conducting the treatment. Each group consisted of 6 to 8 members to discuss. After the students divided into a group and they had understood the technique, then the writer gave speaking exercise to the students.

The third step was closing, after doing the treatment the writer closed the lesson with praying, thanks and greeting.

\section{Post-Test}

The writer gave the post-test to both classes. The implementation of pre-test and post-test were the same. At first, the writer chose the legend story as a topic of narrative text. After the students understood the material, the writer asked students to 
make some groups. Then the writer gave them the title of the story that will be presented in front of the class. After that, the writer gave them 20 minutes to discuss the story. After the students had prepared their story, the students presented it in front of the class. In this case, post-test aimed to investigate the comparison between pre-test before the treatment and post-test after treatment, to know if the story completion technique is effective toward students' speaking skill in both classes, experimental and control class. Also, the post-test aimed to know the difference between the score of the experiment class that was given the treatment and control class was not.

From the pre-test result, in the experiment class, there were 3 students with score 40 got the lowest score and their score in the post-test was increased, student AP with the score 68 , student DF with the score 80, student NP with the score 72.They showed significant improvement from pre-test to posttest. In the pre-test, they were still difficult to speak out because they were limited vocabulary. So they only spoke in a few sentences. It can be seen from the result of the pretest, student $\mathrm{N}$ only spoke a few sentences "the golden snail change in pretty girl aaaaa.... gak tau apa ya" but in the posttest, she showed the improvement in vocabulary, grammar, pronunciation, fluency, and comprehension. It can be seen from her performance in the posttest "I will marry you. But you have to build one thousand temples in one night as a wedding gift, request Roro Jonggrang. Bandung Bondowoso agreed with that condition. Helped by a spirit of the demons, Bandung started to build the temples". In posttest, she showed improvement.

The students in the post-test showed good performances. They spoke in a good fluency and improved their vocabulary. So the listener can understand what they said.The sample of students in this category is shown by student N. It can be seen from the result in the posttest "at once the princes turned into a statue. Knowing this Bandung Bondowoso regretted and he went away into farmland. The farm people called the Prambanan temple". 
While the pretest result is "the golden snail change in pretty girl aaaaa.... gak tau apa ya".

The sample of students in this category is shown by student D. It can be seen from the result in the posttest "someday there was a handsome young man with the supernatural power named Bandung Bondowoso. He had defeated and killed Prabu Baka. Prabu Baka is the king of the kingdom. On seeing Rara Jonggrang's beauty. Bandung fell in love with her". While the pretest result is "in the next day, there is the grandmother who finds the golden snail. And then she is saving the golden snail"

The sample of the students in the excellent category is shown by NW. It can be seen from her result in the posttest "Pati Sidopekso couldn't stay anger any longer. He killed his wife and his term in his wife in life and his child into the river. But before he killed her. He said that her innocent what be proven after he kills her. Immediately the profit river, the turbit river turned into clean and refuse the fragrance. Pati Sidopekso regrated what he had done. He realized that his wife is was innocent then he screamed. Banyu Wangi, Banyu Wangi, Banyu Wangi its means fragrance water. Since the incident happened the river was called Banyu Wangi. So Banyu Wangi was born from the prove of noble and secret love". It was in the excellent category since the spoke grammatically. This improvement was significantly shown from her pretest result "They are got married and have a son. Their son gots Samosir. Samosir is such a lazy boy. When he delivered the food to his father, in the middle of the road he ate the food. Mr. Toba was angry and saying you are the son of the fish". Her speech was fluent, she did not have a pause when she was telling the story. She was speaking in a good diction. She could use her own words to make the story simpler. It means she was good at vocabulary. For grammar, she was fluent in used the past form to tell the story. She even could pronounce words and sentences well.

Based on the result of their pretest and posttest. There are many improvements, they can speak more 
than five or six sentences. While before did the treatment, they only spoke in a few words. Their pronunciation also improved after the treatment.from the explanation above it can be concluded that the story completion technique is effective to improve students' speaking skill.

The statistical calculation showed that the pre-test average in the experimental class was 59, 06 with the lowest score at 40 and the highest score at 80 . The pre-test average in the control class was 60 , 50 with the lowest score of 40 and the highest score of 80 . The post-test average in the experimental class was 79,65 with the lowest score of 64 and the highest score of 92. The post-test average in the control class was 65,00 with the lowest score at 44 and the highest score at 80 . From the data, the writer noticed that story completion technique is effective to improve students' speaking skill of narrative legend story.

The use of Story Completion is an appropriate technique in teaching speaking because the teachers can interestingly teach the material. The advantages of Story Completion as follow:

1. The speaking activities are more interesting. It does not make the students feel bored to sit for hours, so that, the students' motivation in doing the speaking activities is increased.

2. The speaking activities are more active because all of the students should speak and make a story in their own words.

3. The speaking activities can improve the students speaking skills in terms of vocabulary, grammar, pronunciation, comprehension, and fluency.

From the comparison of the result of pre-test and post-test scores between the experimental and control group, the ability to speak in the experimental group was improved than in the control group. It means that the treatment of using Story Completion to the experimental group was successful.

\section{CONCLUSION}

After the research had been conducted and analyzed, the writer concludes that the implementation of 
story completion techniques toward students' speaking ability of senior high school students grade $\mathrm{X}$ was successful. The students speaking ability in narrating the legend story through story completion technique is effective. It can be proven from students' scores of post-test and the result of statistical analysis. The average score of the post-test in the experimental class was 79,65 while the average score of the post-test in the control class was 65,00 which means that the post-test score of the experimental class was higher than the control class, which did not learn narrative legend story through story completion technique. So the experimental class showed significant improvement in their speaking ability. Whereas, the control class did not show any significant development.

The statistical analysis shows that the value of $t_{\text {-counted was }} 9,583$ while the value of $t_{\text {-table }}$ was 2,000 which means $t_{\text {-counted }}$ is higher than $\mathrm{t}_{\text {- }}$ table $\left(\mathrm{t}_{\text {-counted }}>\mathrm{t}_{\text {-table }}\right)$. Based on the result of the statistical analysis above, it means that $\mathrm{H}_{\mathrm{a}}$ is accepted while $\mathrm{H}_{\mathrm{o}}$ is rejected. In other words, using Story Completion technique can improve the students' ability in speaking English.

The writer hopes that the research can be useful for English teachers, students, schools, and the next researchers. The improvement is really important to make the result more effective. Hence, for the improvement, the writer would like to give some advice and suggestions:

1. The students

The students need to be more active in the classroom. A further effort needs to be made by the students to encourage themselves in speaking activities without worries making mistakes in grammar or pronunciation. It gives advantages for the students to develop their skills in speaking. The students can easily understand what they listen to, tell, read and write.

\section{The Teacher}

The teacher should make the class interesting and enjoyable. Here, the use of Story completion contributed to motivating and stimulus the students' ability to speak. The English teacher must also give the students more motivation, to 
make them more confidence in learning English especially speaking skills to daily lives, so they have the background knowledge that reduces the anxiety to tell about the information they will share. The teacher should pay attention to improve the students' speaking activities in the class. Let the students explore their potential and their ability in speaking.

\section{The School}

The school as the place of learning plays an important role to make an effective learning process. The writer hopes this research could give a positive contribution to the school. The school should be able to provide the facilities for the teacher and the students in learning English, especially in learning speaking.

4. For the other researchers

The writer has researched senior high school grade $\mathrm{X}$ successfully using story completion techniques towards students' speaking skills. The writer expects this research can be additional sources for the other researcher who wants to investigate deeper about the implementation of the story completion technique. The writer also hopes that the other researcher can apply the story completion technique to the other relevant level of school.

\section{REFERENCES}

Zhang, S. (2009). The role of input, interaction, and output in the development of oral fluency. English Language Teaching,2(4), 91-100.

Rebecca, J. L. (2003). A Critical Handbook of Children's Literature. Massachuset: Pearson Education, Inc.

Kayi, H. (2006) Teaching Speaking: Activities to Promote Speaking in a Second Language. Nevada: University of Nevada Journal.

Richard \& Renandya. (2002). Methodology In Language Teaching An Anthology of Current Practice. Cambridge: University Press.p.210.

Cole, R.W. (2008). Educating Everybody's Children: Diverse Teaching Strategies for Diverse Students, Revised and Expanded $2^{\text {nd }} e d$. Virginia: Association for Supervision and Curriculum Development (ASCD). 
Cresswell, J. W. (2008). Educational Research: Planning, Conducting and Evaluating Quantitative and Qualitative Research. New Jersey: Pearson Educational Limited.

Nunan, D. (1992). Research Methods in Language Learning. Cambridge: Cambridge University Press.

L.R. Gay and Peter. A (2009), Educational Research Competencies for Analysis and application Sixth Edition, New Jersey: Prentice Hall Inc.

Brown, H. D. (2000). Teaching By Principles: An Interactive Approach to Language Pedagogy $\left(2^{\text {nd }} E d\right)$. America: Longman

Brown, H. D. (2004). Language Assessment: Principles and Classroom Practices. America: Longman.

Spolsky, B., \& Hult, F. M. (2008). The Handbook of Educational Linguistics. Oxford: Blackwell Publishing

Richards, J. C. (2008). Teaching listening and speaking: From theory to practice. Cambridge University Press.

Hornby. (1995). Definition of Speaking Skills. New York: Publisher.
Hinkel, J.(2005). Handbook of Research in Second Language Teaching and Learning. London: Seattle University.

Celce-Murcia, M. (2013). Teaching English in the context of world English. In M. Celce-Murcia, D. M. Brinton, \& M.A. snow (Eds), Teaching English as a Second or Foreign Language (4th ed, pp. 2-14). Boston, MA: National Geographic Learning/Cengage Learning. 